\title{
Determinants of Online Sellers Intention in to Apply Micro Credit
}

\author{
Fermico Karambut*, Hartoyo, Rita Nurmalina and Mukhamad Najib \\ IPB University \\ J1. Raya Pajajaran Bogor, Indonesia \\ *Corresponding author's email: fermico11 [AT] gmail.com
}

\begin{abstract}
The contribution of MSMEs to Indonesia's Gross Domestic Product (GDP) reached 61.41\%, but only about 8\% of MSME players have used e-commerce. One of the government policies to encourage MSMEs going online is to facilitate access to have microcredit (KUR) which has tailored to the e-commerce business model. This study aimed to look at the relationship of demography and characteristics of online business with the intention of to apply microcredit since the location and type of business of MSMEs are mostly not fixed. The data were obtained by online survey to the respondents selected by convenience sampling. This study used descriptive analysis and cross tabulation analysis of 235 respondents who are registered as members of the Indonesian Online Sellers Association. The results of the study showed that only the types of online business and other sources of income were significantly related to the intention in to apply for microcredit. Credit lending through media e-marketplaces could identify proper financing for the type of business for MSMEs. Further research by utilizing e-marketplace merchant database will provide a better description of MSME models for the intention in to apply microcredit.
\end{abstract}

Keywords - e-marketplace, intention, microcredit, MSME, online seller

\section{INTRODUCTION}

The contribution of MSMEs to Indonesia's Gross Domestic Product (GDP) reached 61.41\%, with the number of MSMEs reaching almost 60 million units. However, only around $8 \%$ or as many as 3.79 million MSME players have used online platforms to market their products (Kominfo 2017). For this reason, the government through PP No. 74 of 2017 issued the Economic Policy Package Volume XIV which contains the Roadmap of Electronic-Based National Trade Systems or the E-Commerce Roadmap, which provides direction and steps for preparing and implementing trade transactions based on a series of electronic devices and procedures.

Table 1. Financial institution partners in e-marketplace in Indonesia

\begin{tabular}{|c|c|c|c|c|}
\hline \multirow[t]{2}{*}{ NO. } & \multirow[t]{2}{*}{ MARKET PLACE } & \multicolumn{3}{|c|}{ FINANCE INSTITUTION PERTNERSHIP } \\
\hline & & BANK & LEASING & FINTECH \\
\hline 1. & $\begin{array}{l}\text { TOKOPEDIA } \\
\text { (C2C) }\end{array}$ & $\begin{array}{l}\text { BNI, Mandiri Bank, BSM, BRI } \\
\text { Syariah, BCA, OCBC, DBS, } \\
\text { CTCB, Commonwealth Bank, } \\
\text { Standard Chatered Bank, } \\
\text { Samperna Bank, Sinarmas Bank }\end{array}$ & $\begin{array}{l}\text { BFI Finance Bina Artha, } \\
\text { Kredit Plus, CSUL }\end{array}$ & $\begin{array}{ll}\text { Koinworks, } & \text { Modalku, } \\
\text { Taralite, } & \text { Investree, } \\
\text { Rajadana, Klik ACC }\end{array}$ \\
\hline 2. & $\begin{array}{l}\text { BUKALAPAK } \\
(\mathrm{C} 2 \mathrm{C})\end{array}$ & Mandiri Bank & - & $\begin{array}{l}\text { Koinworks, } \\
\text { Investree }\end{array}$ \\
\hline 3. & $\begin{array}{l}\text { LAZADA } \\
\text { INDONESIA } \\
\text { (B2C) }\end{array}$ & $\begin{array}{l}\text { BNI, CIMB, BCA, } \\
\text { Commonwealth Bank }\end{array}$ & $\begin{array}{l}\text { Bina Artha, } \\
\text { BFI Finance }\end{array}$ & $\begin{array}{l}\text { Koinworks, Modalku, } \\
\text { Taralite, Investree }\end{array}$ \\
\hline 4. & $\begin{array}{l}\text { MATAHARI MALL } \\
(\text { B2C) }\end{array}$ & $\begin{array}{l}\text { Commonwealth Bank, } \\
\text { Amar Bank }\end{array}$ & - & $\begin{array}{l}\text { Crowdo, Taralite, } \\
\text { Investree, Teman Kredit }\end{array}$ \\
\hline
\end{tabular}

Sources: www.tokopedia.com, www.bukalapak.com,pages.lazada.co.id, super. mataharimall.com 
The E-Commerce Roadmap includes financing programs, taxation, consumer protection, education and human resources, communication infrastructure, logistics, cyber security, and the establishment of Roadmap Implementing Management. In term of financing, the government provided microcredit named KUR (Kredit Usaha Rakyat) for MSMEs (Micro Small and Medium Enterprises). The KUR application in e-marketplace is relatively easier because the debtors and their business are existing and clear. Some e-marketplace sites such as $\mathrm{C} 2 \mathrm{C}$ and $\mathrm{B} 2 \mathrm{C}$ types provide micro-credit facilities for merchants (online sellers) that they can access online to partner financial institutions including banks, leasing (finance companies), cooperatives and peer to peer lending (fintech) as seen in Table 1.

In the Regulation of the Minister of Economy No. 6 of 2015 concerning the KUR Implementation Guidelines, the KUR-financed sector only covers agriculture, fisheries, processing industries, and trade sectors related to the three sectors. Based on Permenko 8/2015, the expansion of the trade sector is no longer limited but covers all businesses in the trade sector and some service sectors. The realization of KUR disbursement for the trade sector as of December 31, 2018 reached Rp 64.0 billion or $54.09 \%$ of the total KUR. However, based on Table 2, the increase in KUR distribution in the last 2 years has reached $20.31 \%$ while the increase in trade sector distribution has only reached $2.39 \%$.

Table 2. Data on the realization of KUR per business sector until 31 December 2018

\begin{tabular}{lrrr}
\hline \multicolumn{1}{c}{ Economy Sector } & $\begin{array}{c}\text { Dec-17 } \\
\text { (Rp million) }\end{array}$ & $\begin{array}{c}\text { Dec-18 } \\
\text { (Rp million) }\end{array}$ & \multicolumn{1}{c}{$\begin{array}{c}\text { Increase } \\
\text { (\%) }\end{array}$} \\
\hline Agriculture, Hunting, and Forestry & $16,363,786$ & $27,647,777$ & $68.96 \%$ \\
Fisheries & $1,146,966$ & $1,847,540$ & $61.08 \%$ \\
Processing Industry & $3,866,275$ & $8,830,749$ & $128.40 \%$ \\
Trading & $62,483,026$ & $63,978,838$ & $2.39 \%$ \\
Construction & 0 & 218,820 & $100.00 \%$ \\
Services & $10,401,382$ & $17,241,112$ & $65.76 \%$ \\
Indonesian Labor Placement & 0 & 583,701 & $100.00 \%$ \\
\hline T O T A L & $94,261,435$ & $118,290,743$ & $20.31 \%$ \\
\hline
\end{tabular}

Sources: www.kur.ekon.go.id

Apart from the government's efforts to facilitate financial accessibility, the KUR realization data indicates that there is still low intention of MSMEs in accessing external financing. The cause of the low intention in to apply for microcredit based on the study of Kajehtiran et al. (2016) is the perception of the absence of benefits and the perception of the severity of credit requirements. The study by Thaker et al. (2016) showed that the cash waqf micro business investment model as a source of microfinance in Malaysia was still hindered by subjective attitudes and norms for credit requirements that were difficult to fulfill. The study by Makpotche et al. (2015) on micro-business culture in Benin and Mauritania showed that the factors of secrecy and conservatism had negative effects on intention in borrowing money from banks. Based on the results of the study of Hassman et al. In 2013, micro business owners were not well informed about microcredit and did not have knowledge about the forms of loans that fit their business needs and did not know how and where to apply for the loans.

This study aims to see an overview of intention of the online sellers in to apply for microcredit by analysing its relationship with the demographic factors and characteristics of the sellers. Studies of online sellers related to intentions and demography generally only discuss online purchases (Thamizhvanan and Xavier 2012, Jadhav and Khanna 2017, Ashari et al. 2017, and Ansari and Farooqi 2017). Meanwhile, a study of the online seller generally discussed about the implementation of e-commerce in MSMEs (Savrul et al. 2014, Rahayu and John Day 2015, Venkatesh and Kumari 2015 and Ueasangkomsate 2015). Previous studies on the intention in to apply for credit to the bank were carried out by Abdullah and Wahab (2015), Bizri et al. (2016) and Tolba et al. (2016). However, specific studies on the intention in credit applications through online media have so far not been found.

\section{LITERATURE REVIEW}

Several studies on the relationship or influence of social demographic variables on intention related to technology and MSMEs generally discuss the intentions of online shopping (Thamizhvanan and Xavier 2012, Hsu et al. 2014, Jadhav and Khanna 2017, Ashari et al. 2017, and Ansari and Farooqi 2017) or entrepreneurial intentions (Alibaygi and Pouya 2011, Agyemang et al. 2013, Talas et al. 2013, Katundu and Gabagambi 2014, Singh 2014 and Nquyen 2018). Demographic and non-demographic variables from previous studies adjusted and used in this research included age, sex, education, marital status, ethnicity, religion, length of business period, other sources of income, amount and value of monthly transactions, and monthly working capital requirements. 
Intention in conducting e-commerce transactions or purchases is defined as the intention of buyers to exchange through shopping sites, such as sharing information, maintaining business relationships, and making business transactions (Zwass 1998 in Dachyar and Banjarnahor 2017). Consumer buying intention is caused by external influences including marketing efforts and socio-cultural factors, awareness of the need for product recognition and alternative evaluation (Schiffman and Kanuk, 2010). Studies on online business related to intentions and demography generally discuss about online purchases or buyer sides (Thamizhvanan and Xavier 2012, Jadhav and Khanna 2017, Ashari et al. 2017, and Ansari and Farooqi 2017).

The definition of micro, small and medium enterprises (MSMEs) according to Law No. 20 of 2008: (a) Microbusiness is a productive economic business owned by individuals and/ or individual business entities, having annual sales of a maximum of Rp. 300 million; (b) Small-scale businesses are independent economic productive enterprises carried out by individuals or business entity, having annual sales from more than Rp. 300 million to a maximum of Rp. 2.5 billion, and (c) Medium-sized businesses are independent productive economic enterprises carried out by individuals or business entities, having annual sales from more than Rp. 2.5 billion to a maximum of Rp. 50 billion.

Electronic Commerce (e-commerce) is defined as the process of buying and selling goods, services and information carried out by utilizing electronic networks (Kotler and Keller 2016 whereas the definition of e-marketplace according to Corrot and Nussenbaum (2014) is an online virtual media where buyers and sellers carry out transactions of goods and/or services. According to Bain \& Co (2016), around 40\% of e-commerce sales in Indonesia are estimated to be conducted through B2C/B2B e-commerce sites (business-to-consumer/business-to-business), 30\% sales through C2C sites (consumerto-consumer) and the remaining $30 \%$ through social media, blog stores, and messaging applications. The study of the implementation of e-commerce in MSMEs was previously carried out by Savrul et al. (2014), Rahayu and John Day (2015), Venkatesh and Kumari (2015) and Ueasangkomsate (2015).

Based on Indonesia Law No. 20 of 2008 concerning Micro, Small and Medium Enterprises, in order to increase the sources of financing for Micro and Small Businesses, the Government has made efforts to develop funding sources from bank loans and non-bank financial institutions. Meanwhile according to Law No. 1 of 2013, Microfinance Institutions (MFIs) are financial institutions specifically established to provide business development services and community empowerment, through loans or financing in micro-scale businesses to members and communities, deposit management, and provision of business development consulting services that are not solely earning profits. Previous studies on the intention in to apply for credit to the bank were previously carried out by Abdullah and Wahab (2015), Bizri et al. (2016) and Tolba et al. (2016).

\section{RESEARCH HYPOTHESES}

This study would like to see whether the intention of online sellers in to apply for microcredit have an association relationship with the factors of demography and characteristics of online business. The profile of respondents based on demography was divided into six criteria: the age group, gender, education, marital status, ethnicity and religion while the profile of the respondents based on the characteristics of online business was divided into seven criteria: time length in running online business, whether online business was the main income, other sources of income, types of online business, number of transactions per month, amount per transaction, and amount of monthly working capital.

The results of Premalatha's (2014) study showed that five variables of demographic; age, gender, educational level, monthly income and types of savings were significant related to the intention in receiving internet banking services. The study by Wickramasinghe and Fernando (2017) proved that the borrowers' socio-demographic characteristics included age, number of members in the household, number of dependents, education level, residence location and community type factor influenced the use of microcredit by low-income communities in Sri Lanka. Previous research related to the nondemographic factor conducted by Alibaygi and Pouya (2011) on the younger generation in Kermanshah Province of Iran showed that six determinant factors of relations with parents, attitudes toward agriculture, work experience, intention to migrate, parents' income level, and parent education level statistically were significant in influencing entrepreneurial intentions.

Hypothesis 1: Demographic factors have an association relationship with the intention to apply microcredit, with the statistical hypothesis:

- $\quad \mathrm{H}_{0}$ : Demographic factors do not have an association relationship with the intention in to apply microcredit

- $\quad \mathrm{H}_{1}$ : Demographic factors have an association relationship with the intention in to apply microcredit

The hypothesis tests used as assumptions of the association relationship between the demographic factor and intention of online sellers in to apply for microcredit are as follows:

H1a: Age group has an association relationship with the intention in to apply microcredit.

H1b: Gender has an association relationship with the intention in to apply microcredit.

H1c: Educational level has an an association relationship with the intention in to apply microcredit. 
H1d: Marriage status has an association relationship with the intention in to apply microcredit.

H1e: Ethnic has an association relationship with the intention in to apply microcredit.

H1f: Religion has an association relationship with the intention in to apply microcredit.

H1g: Another source of income has an association relationship with the intention in to apply microcredit

Hypothesis 2: Business characteristics factors have an association relationship with the intention in to apply microcredit, with the statistical hypothesis:

- $\quad \mathrm{H}_{0}$ : Business characteristics factors do not have an association relationship with the intention in to apply microcredit

- $\quad \mathrm{H}_{1}$ : Business characteristics factors have an association relationship with the intention in to apply microcredit

The hypothesis tests used as assumptions of the association relationship between the business characteristics factor and intention of online sellers in to apply for microcredit are as follows:

H2a: Period of online business has an association relationship with the intention in to apply microcredit.

$\mathrm{H} 2 \mathrm{~b}$ : Type of online business has an association relationship with the intention in to apply microcredit

H2c: Existing credit facilities has an association relationship with the intention in to apply microcredit

H2d: Online to apply has an association relationship with the intention in to apply microcredit

H2e: Monthly frequency of online transactions has an association relationship with the intention in to apply microcredit.

H2f: Amount per transaction has an association relationship with the intention in to apply microcredit

$\mathrm{H} 2 \mathrm{~g}$ : Amount of working capital needs has an association relationship with the intention in to apply microcredit

\section{RESEARCH METHOD}

This research used an exploratory approach and surveys on the online sellers. Survey method was used to collect primary data obtained directly from the respondents who filled out the questionnaire or did the online interviews. The questions in the questionnaire were divided into two, the demographic section and business characteristics, while the type of questions used in the questionnaire are open questions and closed questions. Open questions are questions with direct answers to get a direct picture of the perceptions of online sellers about microcredit. Closed questions are a form of questions with several alternative answers for respondents and response ranges that use a five-point Likert scale where point $1=$ strongly disagree to point $5=$ strongly agree

Sample collection in this study used a convenience sampling method, and the respondents ( 235 people) were the members of the Indonesian Online Sellers Association (APOI) who provided responses to questionnaires sent or by online interviews. The criterion of the respondents is those who have been running business online at e-marketplace sites for at least 6 months. The samples collected were 235 people or $51.53 \%$ of the 456 respondents who were sent questionnaires online. The analytical methods to be used in this study included descriptive analysis and cross tabulation analysis of the frequency and percentage of two or more variables simultaneously. Descriptive analysis was used to see the concentration and distribution of the respondent data while cross tabulation analysis was used to see the correlation between the variables of demography and business character (category) and the tested variable of intention in to apply for microcredit. Chi-square testing begins with formulating hypotheses $\mathrm{HO}$ and $\mathrm{H} 1$. The null hypothesis (H0) if there is no significant relationship between two variables and one hypothesis (H1) if there is a significant relationship between the two variables. The calculated value $\mathrm{X}^{2}$ chi-square is obtained by the formula:

$$
\chi_{\text {calculated }}^{2}=\sum_{j=1}^{k} \sum_{i=1}^{m} \frac{\left[O_{i j}-E_{i j}\right]^{2}}{E_{i j}}
$$

The results obtained in the Chi-square analysis with using the SPSS for Windows version 15 program, which is value Asymp.Sig (2-sided) Chi-Square count where if the value is Asymp.Sig (2-sided) Chi-Square $>\alpha(0.05)$, then $\mathrm{H}_{0}$ is accepted and if the value is Asymp.Sig (2-sided) Chi-Square $>\alpha(0.05)$, then $\mathrm{H}_{0}$ is rejected or $\mathrm{H}_{1}$ is accepted

\section{RESULTS AND DISCUSSION}

\section{Intention in To apply for Microcredit}

Analysis of the level of intention of respondents of online sellers by using an index in the form of 'top two boxes' obtained from the calculation of the percentage of respondents who gave answers to 'intent' and 'very intent'. For a scale of 
1-5, the credit application intention index is obtained from the percentage of respondents who answered on a scale of 4 and 5 while the level of not intent of the respondents was obtained from the percentage of respondents who answered on a scale of 1,2 and 3 (very not intent, not intent and neutral)

Online business respondents who expressed intention or intention to apply for microcredit amounted to 154 people while those who stated that they did not have an intention were only 81 people. The respondents categorized as having an intention consisted of 22 people $(9.38 \%)$ who stated 'very intent', 132 people $(56.17 \%)$ who stated 'intent". Respondents who were categorized as not having an intention consisted of 3 people $(1.28 \%)$ who stated 'very unintentional, 32 people $(13.62 \%)$ who stated 'unintentional' and 46 people $(19.57 \%)$ who stated 'neutral'

\section{The Respondent Demography}

The average age of respondents of online sellers is 33.1 years with a median of 32 years and standard deviation of 6.46 , or the distribution of age data is relatively centralized. The age range of online sellers is around 21 years - 53 years belonging to the groups of millennials (1982 - 2001) and generation X (1966 - 1981) based on the KPMG category (2017).

Table 3. Distribution of respondents based on demographic factors

\begin{tabular}{|c|c|c|c|c|c|c|c|}
\hline \multirow{3}{*}{ Demographics } & \multicolumn{6}{|c|}{ Intention in Micro Credit Online To apply } & \multirow{3}{*}{$\begin{array}{c}\text { Asymp. Sig. } \\
\text { (2-sided) }\end{array}$} \\
\hline & \multicolumn{2}{|c|}{ Have Intention } & \multicolumn{2}{|c|}{ No Intention } & \multicolumn{2}{|c|}{ TO T A L } & \\
\hline & Frequency & $\%$ & Frequency & $\%$ & Frequency & $\%$ & \\
\hline \multicolumn{8}{|l|}{ Ages Group } \\
\hline$-<37$ years & 113 & 64.48 & 52 & 31.52 & 165 & 100.00 & \multirow{2}{*}{0.177} \\
\hline$-\geq 37$ years & 41 & 58.57 & 29 & 41.43 & 70 & 100.00 & \\
\hline \multicolumn{8}{|l|}{ Gender } \\
\hline - Male & 114 & 66.67 & 57 & 33.33 & 171 & 100.00 & \multirow{2}{*}{0.542} \\
\hline - Female & 40 & 62.50 & 24 & 37.50 & 64 & 100.00 & \\
\hline \multicolumn{8}{|l|}{ Education Level } \\
\hline - Under Graduated & 77 & 63.11 & 45 & 36.89 & 122 & 100.00 & \multirow{2}{*}{0.251} \\
\hline - High School & 77 & 68.14 & 36 & 31.86 & 113 & 100.00 & \\
\hline \multicolumn{8}{|l|}{ Marital Status } \\
\hline - Married & 115 & 66.86 & 57 & 33.14 & 172 & 100.00 & \multirow{2}{*}{0.288} \\
\hline - Not Married & 39 & 61.90 & 24 & 38.10 & 63 & 100.00 & \\
\hline \multicolumn{8}{|l|}{ Ethnic } \\
\hline - Java & 59 & 66.29 & 30 & 33.71 & 89 & 100.00 & \multirow{2}{*}{0.482} \\
\hline - Non-Java & 95 & 65.07 & 51 & 34.93 & 146 & 100.00 & \\
\hline \multicolumn{8}{|l|}{ Religion } \\
\hline - Islam & 112 & 66.67 & 56 & 33.33 & 168 & 100.00 & \multirow{2}{*}{0.649} \\
\hline - Non-Islam & 42 & 62.69 & 25 & 37.31 & 67 & 100.00 & \\
\hline \multicolumn{8}{|l|}{ Source of Other Income } \\
\hline - Employee salary / wages & 70 & 69.31 & 31 & 30.69 & 101 & 100.00 & \multirow{3}{*}{$0.086 * * *$} \\
\hline - Offline Business & 65 & 67.71 & 31 & 32.29 & 96 & 100.00 & \\
\hline - Not Available & 19 & 50.00 & 19 & 50.00 & 38 & 100.00 & \\
\hline Remarks: Ho rejected at & $\begin{array}{l}p \text { value }<0.0 \\
p \text { value }<0.0 \\
p \text { value }<0.1\end{array}$ & & & & & & \\
\hline
\end{tabular}

The percentage of the age group $<37$ years old who have the intention to apply for credit was also greater at $68.48 \%$. But the value of Asymp. Sig. (2-sided) Pearson Chi-Square test results on age groups showed a significance value of 0.177 or $>\alpha$ of 0.05 so that hypothesis H1a was rejected or the age group factor has no association with the intention of online sellers to apply for microcredit. This finding supported the study of Thamizhvanan and Xavier (2012), Jadhav and Khanna (2017), and Nguyen (2018). Male respondents who have the intention to apply for credit are more than female respondents, namely 171 people (72.77\%). This finding supports the study of Thamizhvanan and Xavier (2012). The results of the APJJI survey (2017) also showed that men were slightly more $(51.43 \%)$ than women in using the internet. The percentage of male respondents who have intention in to apply for credit is also slightly larger at $66.67 \%$. Men are generally more consistent using the internet for work / business purposes compared to women. Significance test produces a value of 0.542 greater than 
0.05 so that the H1b hypothesis was rejected or gender factors do not have an association relationship with the intention of online sellers to apply for micro credit. This finding supports Singh's (2014) and Ansari and Farooqi (2017) study

The distribution of the highest number of respondents according to education level was in the group of scholars who had the intention to apply for credit as many as 122 people or $51.91 \%$ of all respondents. The results of APPJI's survey showed that the penetration of internet use by the community with S1 education level reaches $79.23 \%$, but the percentage of respondents with non-graduate education with the intention to apply for credit is also greater, namely $68.14 \%$. This shows that the level of education is not related to the intention of to apply credit online. Significant test also produces a value of 0.251 greater than 0.05 so that the hypothesis $\mathrm{H} 1 \mathrm{c}$ was rejected or the education level factor is not significantly related to the intention of online sellers to apply for microcredit. This finding supported the study of Thamizhvanan and Xavier (2012), Talas et al. (2013), Jadhav and Khanna (2017), and Nguyen (2018). Online sellers who were respondents in the study were married with 172 people (73.19\%). Married respondents also had a higher percentage of intention (66.86\%) compared to unmarried respondents $(61.90 \%)$. This is because respondents who are still married tend to be more aggressive because online business partners have status as employees so there are other sources of income if online sellers fail. Significant test produces a value of 0.288 greater than 0.05 so that the hypothesis H1d was rejected or the factor of marital status does not have an association relationship with the intention of submitting microcredit.

Respondent's ethvicity and religion were dominated by Javanese (37.87\%) and Islam (71.49\%). This data was in accordance with Indonesian population data published by the Central Bureau of Statistics (BPS 2010). Muslim respondents have a greater percentage of intention (66.67\%) than those of non-Javanese ethnicity (62.69\%), but the percentage of intention among respondents of Javanese and Non-Javanese was relatively the same. Significant tests produce values of 0.482 (ethnicity) and 0.649 (religion) which are greater than 0.05 so the H1e hypothesis and hypothesis H1f are rejected or ethnic and religious factors do not have an association relationship with the intention of online businesses to apply for microcredit. This finding supports the study of Katundu and Gabagambi (2014).

Based on other sources of income, the largest group of respondents with the highest intention to apply for credit $(69.31 \%)$ are respondents who are employees. Flexible character accommodates employees whose working time is bound to keep running an online business by utilizing free time or holidays. This group represents employees who want to have their own business by doing business online and planning to raise their business so that they need additional capital. The percentage of intention to apply for the smallest credit is indicated by a group of online businessmen who do not have a side income of $50.00 \%$. This is due to the perception of the difficulty of obtaining credit facilities from banks if they do not have proof or place of business. Significant test produces a value of 0.093 which is significant at the level of 0.10 so that the hypothesis H1f is accepted or other sources of income factors are significantly related to the intention of online businesses to apply for microcredit. The findings of other sources of income have to do with the intention of supporting the study of Talas et al. (2013), Agyemang et al. (2013) and Jadhav and Khanna (2017).

Based on testing of the demographic relationship of respondents to the intention of submitting microcredit using the chi-square test, it can be concluded that demographic factors (age, sex, education, marital status, ethnicity and religion) did not have a significant relationship to respondents' intention to microcredit but other source of income was significantly related or H1 was partly proven. Previous research which also proved that demography did not influence intention was carried out by Hsu et al. (2014) which proved that control variables of gender, age, education, experience, and income, did not have significant influences on the intention in buying again on online shopping sites in Taiwan. The results of Premalatha's (2014) study showed that of the seven demographic variables related to the intention in receiving internet banking services, only five variables of age, gender, educational level, monthly income and types of savings were significant. Also, the variables of marital status and place of residence were not significant. The research by Jadhav and Khanna (2017) also proved that there was no significant difference between attitudes toward students' online shopping behavior in Mumbai (India) and demographic factors of gender, education, age group, location of residence and household income. Likewise, the study of Gundes and Sazkaya (2018) which analyzed the factors influencing adoption and intention in using innovative banking products for students of the Bahçeşehirdi University in Istanbul, Turkey proved that demographic factors were not influential.

However, in the context of the application and use of credit facilities, demographic factors both in whole and in part significantly influenced intention. The study by Kajenthiran et al. (2017) on the intention in seeking micro-credit for young people in Sri Lanka proved that the demographic factor that had a significant influence on the intention in to apply for microcredit was only the number of family members. Gender, age, educational qualification and average family income were not significant. The study by Wickramasinghe and Fernando (2017) proved that the demographic factor influenced the use of microcredit by low-income communities in Sri Lanka. The borrowers' socio-demographic characteristics included age, number of members in the household, number of dependents, education level, residence location and community type.. Meanwhile the research by Amin (2012) proved that intention in the use of credit cards for Islamic banks in Malaysia is significantly affected by demographic factors of age (young customers), marital status, religion and education level, but they were not significant with age (old customers) and gender. 
In this study, the tendency of homogeneity of respondents is a factor that supports the demography of online sellers which did not have a significant relationship with the intention in to apply for microcredit. As many as 207 respondents (88.09\%) do business online /live in Java, where 151 people (64.43\%) are concentrated in Jakarta, Bogor, Depok, Tangerang and Bekasi. The concentration was caused by 187 respondents (79.57\%) working as distributors/resellers. The reason for online sellers to choose a place for business in the area of Jakarta and its surroundings is because Jakarta is a national trade center where almost all goods are available. This is in accordance with McKinsey's findings (2018) that $42 \%$ of e-commerce merchants i.e. drop shippers or resellers live in Jakarta. Thamizhvanan and Xavieri (2012) research proved that online shopping is only influenced by gender and is not significant by age, education level, duration of daily internet usage and ownership of credit cards or internet banking facilities.

Another factor causing the demography of online sellers not to have a significant relationship with intention in microcredit is the character of e-commerce which are (1) Ubiquity - e-commerce technology is available everywhere including at work, at home and elsewhere and can be accessed via mobile devices at anytime, (2) Global reach - technology reaches national boundaries across the earth, (3) Universal standards - there is a set of technological standards, (4) Wealth videos, audio and text messages are possible to be available, (5) Interactivity - technology works through interaction with users, (6) Information density - this technology reduces information costs and improves quality, (7) Personalization/Customization - technology enables personalized messages to be sent to individuals or groups and (8) Social technology - user-created contents and social networks. This advantage has made every online sellers have the same opportunity to apply for microcredit through e-marketplace. Since it can be accesed by everyone, we can conclude that demographic of online sellers didn't influence the intention in to apply for microcredit

\section{The Characteristics of of Online Business}

A total of 136 people $(88.31 \%$ ) out of 154 respondents who have the potential to apply for credit have been running online businesses for more than 2 years. Financial institutions, especially banks, generally provide a minimum two-year business requirement for credit applications to ensure business continuity. This credit requirement was generally understood by online sellers so that respondents who have run an online business for more than two years have a percentage of intention to apply for a larger credit, which is $86.00 \%$. Significant test produces a value of 0.081 which wass significant at the level of 0.10 so that the hypothesis $\mathrm{H} 2 \mathrm{a}$ was accepted or the old factor of business has an association with the intention of online businesses to apply for micro credit A group of 131 respondents (85.06\%) from respondents who intend to apply for credit to business groups are distributors / resellers. This is in accordance with McKinsey's findings (2018) that the majority of ecommerce merchants were drop shipper or reseller. The percentage of intention to apply for credit for distributor respondents is also greater than the producer respondents, which is $66.84 \%$. This was due to the character of the distribution business that does not require too much capital but often so that it is suitable for unsecured credit facilities offered through e-marketplace sites. Significant test produces a value of 0.361 which was greater than 0.05 so the hypothesis $\mathrm{H} 2 \mathrm{~b}$ is rejected or the type of online business factor did not have an association relationship with the intention of online businesses to apply for micro credit

The majority of respondents, 126 people (53.62\%) stated that they already had credit facilities from financial institutions. The group of respondents who already have or do not have credit facilities had almost the same intention to apply for online credit, which is around 65\%. Significant test produces a value of $1.00(>0.05)$ so that the H2c hypothesis was rejected or the credit facility factor currently held is not significantly related to the intention of to apply for micro credit. Based on the experience of to apply for online credit, the largest group of respondents who had the highest intention to apply for credit $(73.81 \%)$ were respondents who had already submitted a credit proposal. This is because this group has felt the benefits or advantages of this system so that a positive attitude and intention have been formed. Significant test produces a value of 0.003 which is significant at the 0.01 level so that the H1d hypothesis was accepted or the experience factor of to apply for online credit is significantly related to the intention of online businesses to apply for micro credit. 
Table 5. Distribution of other income of the respondents beside from their online business

\begin{tabular}{|c|c|c|c|c|c|c|c|}
\hline \multirow{3}{*}{$\begin{array}{c}\text { Characteristic of Online } \\
\text { Business }\end{array}$} & \multicolumn{6}{|c|}{ Intention in Micro Credit Online To apply } & \multirow{3}{*}{$\begin{array}{l}\text { Asymp. Sig. } \\
\text { (2-sided) }\end{array}$} \\
\hline & \multicolumn{2}{|c|}{ Have Intention } & \multicolumn{2}{|c|}{ No Intention } & \multicolumn{2}{|c|}{ TOTA L } & \\
\hline & Frequency & $\%$ & Frequency & $\%$ & Frequency & $\%$ & \\
\hline \multicolumn{8}{|l|}{ Period of Business } \\
\hline$-\geq 24$ months & 136 & 68.00 & 64 & 32.00 & 200 & 100.00 & \multirow{2}{*}{$0.081 * * *$} \\
\hline$-<24$ months & 18 & 51.43 & 17 & 48.57 & 35 & 100.00 & \\
\hline \multicolumn{8}{|l|}{ Type of online business } \\
\hline - Reseller / Distributor & 131 & 66.84 & 65 & 33.16 & 196 & 100.00 & \multirow{2}{*}{0.361} \\
\hline - Producer & 23 & 58.97 & 16 & 41.03 & 39 & 100.00 & \\
\hline \multicolumn{8}{|c|}{ Existing credit facilities from financial institution } \\
\hline - Have & 83 & 65.87 & 43 & 34.13 & 126 & 100.00 & \multirow{2}{*}{1,000} \\
\hline - Don't have & 71 & 65.14 & 38 & 34.86 & 109 & 100.00 & \\
\hline \multicolumn{8}{|c|}{ Experience in online to apply of micro credit } \\
\hline - Have & 93 & 73.81 & 33 & 26.19 & 126 & 100.00 & \multirow{2}{*}{$0.003 *$} \\
\hline - Don't have & 61 & 55.96 & 48 & 44.04 & 109 & 100.00 & \\
\hline \multicolumn{8}{|c|}{ Berapakah rata-rata jumlah transaksi online per bulan? } \\
\hline$-<14$ kali & 22 & 66.67 & 11 & 33.33 & 33 & 100.00 & \multirow{3}{*}{0.977} \\
\hline$-15-30$ kali & 40 & 66.67 & 20 & 33.33 & 60 & 100.00 & \\
\hline - > 30 kali & 92 & 64.79 & 50 & 35.21 & 142 & 100.00 & \\
\hline \multicolumn{8}{|c|}{ Berapakah nilai per transaksi online? } \\
\hline$-<$ Rp 1 juta & 117 & 66.48 & 59 & 33.52 & 176 & 100.00 & \multirow{3}{*}{0.376} \\
\hline - Rp 1 juta - Rp 5 juta & 24 & 70.59 & 10 & 29.41 & 34 & 100.00 & \\
\hline - > Rp 5 juta & 13 & 52.00 & 12 & 48.00 & 25 & 100.00 & \\
\hline \multicolumn{8}{|c|}{ Berapakah kebutuhan modal kerja? } \\
\hline - Rp 10 juta -25 juta & 81 & 66.94 & 40 & 33.06 & 121 & 100.00 & \multirow{3}{*}{$0.093 * * *$} \\
\hline - Rp 25 juta - Rp 50 juta & 46 & 73.02 & 17 & 26.98 & 63 & 100.00 & \\
\hline$->\operatorname{Rp} 50$ juta & 27 & 52.94 & 24 & 47.06 & 51 & 100.00 & \\
\hline . & $\begin{array}{l}e<0.01 \\
e<0.05 \\
e<0.10\end{array}$ & & & & & & \\
\hline
\end{tabular}

The group of respondents who intend to apply for credit according to the highest average online business transactions in one month were dominated by 92 people (59.74\%) with transactions $>30$ times per month, while the largest average value in one transaction was 86 people $(55.84 \%)$ with transaction value of 100 thousand -1 million rupiah. The highest percentage of intention to apply for credit for the number of transactions is a group that sells 15-30 times a month (66.67\%) and groups with a transaction value of $\mathrm{Rp} 1$ million - Rp 5 million (70.59\%). This information matches the price range of the products that are most often sold online, namely fashion / clothing and shoes with fast turnover. Significant test produces a value of 0.977 (number of transactions) and 0.376 (transaction value) which is greater than 0.05 so that the H1e hypothesis and hypothesis H1f were rejected or factors of transaction and transaction value did not have an association relationship with the intention of online businesses to apply for microcredit. The amount of business capital needed is based on information from 127 respondents (82.46\%) who have the intention to apply for credit below Rp 50 milion. The largest group of intensity is 145 respondents (61.70\%) stating that they need capital between $\mathrm{Rp} 25$ million - Rp 50 million to run an online business. This group is a group that requires large working capital but does not have collateral. The probability value (p-value) produces a value of 0.093 or significant at the level of 0.10 so that the $\mathrm{H} 2 \mathrm{~g}$ hypothesis is accepted or the large factor of capital needed had an association relationship with the intention of online businesses to apply for micro credit.

Based on the testing of the relationship between respondents 'online business characteristics to the intention of submitting microcredit using the chi-square test, it can be concluded that only a part of the characteristics of online businesses have a significant relationship to respondents' intentions of microcredit, namely the long time doing business online $(\mathrm{H} 2 \mathrm{a})$ 0.081 , experience to apply for online credit $(\mathrm{H} 2 \mathrm{c})$ with a significant value of 0.003 and working capital requirements $(\mathrm{H} 2 \mathrm{~g})$ with a significance value of 0.093 . The results of this chi-square test only prove the truth of Hypothesis 2 . These results meet the conclusion of Singh's (2014) study of the influence of demographic variables on entrepreneurial intentions which prove that income, family business background and parent work in addition to age, gender and background significantly influential 
education. Whereas Ansari and Farooqi (2017) research on the influence of demographic variables on online shopping intention proves that income, age and experience factors have a moderating influence on attitudes.

Table 6. Distribution of sources of income other than the respondent's online business

\begin{tabular}{lccc}
\hline \multirow{2}{*}{ Other Source of Income } & \multicolumn{2}{c}{ Income from Online Business } & \multirow{2}{*}{ T O T A L } \\
\cline { 2 - 3 } & Primary & Not Primary & \\
\hline Employee & 42 & 59 & 101 \\
\hline Offline Business & 32 & 64 & 96 \\
\hline Not Available & 35 & 3 & 38 \\
\hline \multicolumn{1}{c}{ T O T A L } & 109 & 126 & 235 \\
\hline
\end{tabular}

Based on the question on income sources outside from the online business, 101 people (42.98\%) stated that they still relied on their salaries as employees, 96 people $(40.85 \%)$ stated that other sources of income came from offline businesses, and 38 people (16.17\%) stated that they did not have sources of income besides online business. Furthermore, as many as 109 people $(46.38 \%)$ stated that online sellers is the main income source, and 126 people (53.62\%) stated that online business is not the main income source. This means that out of a total of 285 respondents, only 35 people (14.89\%) focused on running their online business. The ease and small amount of capital in doing online business is a driving factor in the increasing number of online sellers. However, online business has not been used as the only source of income. The flexible character of the online business makes this business run anytime without time limits. Employees who work or offline businessmen can continue to run an online business by utilizing their free time outside working hours or holidays. In addition to business time, the market is also not limited by geographical location.

Based on the type of online business, the majority of respondents were distributors/ resellers amounting to 196 people $(83.40 \%)$ and only 39 people $(16.60 \%)$ were producers. As online sellers, the resellers must guarantee the availability and speed of delivery of goods ordered by consumers. Therefore, capital requirements for stocks become less but the turnover period is fast. Credit facility for working capital that suitable for this kind of business is a revolving loan. Drawdown fund amount can be adjusted to the needs (for example to buy stock) as bridging facility while the delivery of ordered good hasn't paid yet. The used loan will be settled when the payment from the e-marketplace is received. Therefore, online sellers only pay current interest of utilized funds. This need is different with producers' who have to allocate capital both for investment (machinery / production equipment and storage warehouses) and for working capital (raw materials, labor, production costs, etc.). The type of working capital credit that proper with production business is installment loans or term loans. The Indonesian Bankers Association (2014) distinguishes credit based on the time period as follows Short Term Loans, such as working capital loans for trade, industry and other sectors, Medium Term Loans, such as investment loans for vehicle purchase and working capital loans for construction, and Long-term Loans, such as investment credit for the development of factories, hotels, toll roads and others. Based on above classification, distributor business supposed to be offered by short term loan while producers suitable with long or medium term of loan to buy production equipment or raw materials.

\section{CONCLUSION AND MANAGERIAL IMPLICATIONS}

The results of the descriptive analysis of the demographics of respondents of online business people in this study were the majority of those under the age of 37 years, male sex, final education, marriage status, ethnic Javanese and Muslim. While the characteristics of online businesses are the majority of respondents are already in business for more than 2 years, do not consider online business as the main income and state that they still rely on salaries as employees as a source of income outside of online business. The respondent group is dominated by distributors / resellers, making sales transactions> 30 times per month and the value per transaction of 100 thousand - 1 million rupiah. The value of expenditure or business capital requirements per month is a majority of under Rp 50 million per month.

The results of cross tabulation analysis of seven demographic factors and seven characteristics of online business concluded that only sources of income other than online business, long time doing business online, online credit application experience and working capital needs that have an association relationship with intention in to apply for micro credit. The category of respondents who have the smallest significant value is the experience of to apply for online credit before. This category must receive special attention, especially because groups in this category who have greater intentions are groups that have previously submitted. When compared with the working capital needs category where the group with the highest interest is a group with working capital requirements between Rp. 25 million to Rp. 50 million. The findings provide information that segments of online businesses that have received facilities below Rp. 25 million (loans without collateral) still need additional capital but do not have collateral that can be pledged. 


\section{REFERENCES}

- Abdullah NSN, Wahab NA. 2015. Investigating factors affecting the intention to use Islamic personal financing. International Journal of Management Studies. 22(S):47-60.

- Agyemang IK, Deh IY. Asuamah SY. 2013. Socio-Demographics effect in factors that shape decision to start own business. Journal of Small Business and Entrepreneurship Development. 1(1):34-41

- Alibaygi A, Pouya M. 2011. Socio-demographic determinants of entrepreneurial intentions: A case from Iran. African Journal of Business Management. 5(34): 13316-13321. DOI: 10.5897/AJBM11.2168

- Amin H. 2012. Patronage factors of Malaysian local customers toward Islamic credit cards. Management Research Review. 35(6): 512-530. DOI 10.1108/01409171211238271

- Ansari S, Farooqi R. 2017. Moderating effect of demographic variables on attitude towards online shopping: An empirical study using PROCESS. IOSR Journal of Business and Management. 19(11): 47-54.

- Ashari BH, Wibawa BM, Persada SF. 2017. Analisis deskriptif dan tabulasi silang pada konsumen online shop di instagram (Studi kasus 6 universitas di kota Surabaya). Jurnal Sains dan Seni ITS. 6(1):17-21.

- Asosiasi Penyelenggara Jasa Internet Indonesia. 2017. Penetrasi Pengguna Internet Indonesia 2017. Jakarta (ID): APJII

- Bain \& Co. 2016. Can Southeast Asia Live Up to Its E-commerce Potentials? Singapore (SG). Bain \& Company Inc

- Bank Indonesia. 2015. Profil Bisnis Usaha Mikro, Kecil dan Menengah. Jakarta (ID): BI.

- Bizri R, Jardali R, Bizri MF. 2017. Financing family firms in the Middle East: the choice between Islamic and conventional finance. International Journal of Entrepreneurial Behavior \& Research. DOI 10.1108/IJEBR-102016-0349.

- Corrot P, Nussenbaum A. 2014. Marketplace: The Future of E-commerce. Paris (SG): Mirakl Marketplace Situs@.

- Dachyar M, Banjarnahor L. 1997. Factors influencing purchase intention towards consumer-to-consumer ecommerce. Intangible Capital. 13(5):946-968.

- Gundes F, Sazkaya MK. 2018. Study of consumers' adoption and behavioural intention toward innovative banking products. Kafkas University. Faculty of Economics and Administrative Sciences. Journal. 9(17): 101-130. DOI:10.9775/kauiibfd.2018.005.

- Hassman M, Dafna S, Raphael B. 2013. Micro-enterprise lack of access to credit - The israeli case. International Journal of Business and Economic Development. 1(3):1-14

- Hsu M H, Chang C M, Chu K K, Lee Y J. 2014. Determinants of repurchase intention in online group-buying: The perspectives of DeLone \& McLean IS success model and trust. Computers in Human Behavior. 36:234-245.

- Ikatan Bankir Indoensia. 2014. Mengelola Kredit Secara Sehat. Jakarta (ID): Gramedia.

- Jadhav V, Khanna M. 2017. A demographic study of online buying behavior among college students in Mumbai, India. South Asian Journal of Management. 24(4): 11-34.

- Kajenthiran K, Karunanithy M, Achchuthan S. 2016. Antecedents of youth's intentions in seeking microcredit: Evidence from Jaffna district, Sri Lanka. International Journal of Accounting \& Business Finance. 78-99.

- Katundu MA, Gabagambi DM. 2014. Demographic Determinants of Tanzanian Graduates' enterpreneurial entry intentions: the casse of University of Dar-es-salaam. Research Journal of Economics, Business and ICT. 9(1):1-7.

- Indonesian Ministry of Communication and Informatics. 2017. Kolaborasi Mendorong Delapan Juta UMKM Go Online. Siaran Pers No. 222/HM/KOMINFO/11/2017. [Published 2017 November 15]. [Downloaded 2018 Juni 29]. Avai;able at: https://kominfo.go.id/content/detail/11484/siaran-pers-no-222hmkominfo112017

- Kotler P, Keller KL. 2016. Manajemen Pemasaran Edisi Ke-12 Jilid Pertama. Jakarta (ID): Indeks

- KPMG. 2017. Retail Payments in Indonesia Who Will drive The Cashless Revolution? Jakarta (ID): KPMG International

- Laudon, Kenneth C dan Traver, Carol G. (2016). E-Commerce 2016 (12th Edition). New Jersey (US): Pearson.

- Makpotche M, Logossah K, Amewokunu Y, Lawson-Body A dan Sedzro K. 2015. Impact of Cultural Beliefs on Entrepreneurs' Intention to use Bank Loans. Journal of Applied Finance \& Banking. 5(4):11-32.

- Mc.Kinsey \& Co. 2018. The Digital Archipelago: How Online Commerce is Driving Indonesia's Economic Development. Jakarta (ID): McKinsey \& Company

- Nguyen C. 2018. Demographic factors, family background and prior self-employment on entrepreneurial intention - Vietnamese business students are different: why? Journal of Global Entrepreneurship Research. 8(10):1-17. 
- Pemerintah Indonesia. 2008. Undang-Undang tentang Usaha Mikro, Kecil dan Menengah. UNDANG-UNDANG REPUBLIK INDONESIA NOMOR 20 TAHUN 2008.

- Pemerintah Indonesia. 2013. Undang-Undang tentang Lembaga Keuangan Mikro. UNDANG-UNDANG REPUBLIK INDONESIA NOMOR 1 TAHUN 2013.

- Premalatha JJR. 2014. Influence of demographic profile on acceptance of internet banking in a non metro city in Tamil Nadu, India: An empirical study. Journal of Internet Banking and Commerce. 19(3): 1-15.

- Rahayu R, Day J. 2015. Determinant factors of e-commerce adoption by SMEs in Developing Country: Evidence from Indonesia. Procedia - Social and Behavioral Sciences. 195: 142 - 150.

- Savrul M, Incekara A, Sener S. 2014. The potential of e-commerce for SMEs in a globalizing business environment. Procedia - Social and Behavioral Sciences. 150: 35 - 45.

- Schiffman dan Kanuk. 2010. Perilaku Konsumen. Edisi 7. Jakarta (ID): Indeks.

- Singh I. 2014. Role of demographic variables in the formation of entrepreneurial intention. IOSR Journal of Business and Management. 16(12): 20-25.

- Talaş E, Çelik AK, Oral IO. 2013. The Influence of demographic factors on entrepreneurial intention among undergraduate students as a career choice: the case of a Turkish University. American International Journal of Contemporary Research. 3(12): 22-31.

- Thaker MABMT, Mohammed MO, Duasa J, Abdullah MA. 2016. The behavioral intention of micro enterprises to use the Integrated Cash Waqf Micro Enterprise Investment (ICWME-I) Model as a source of financing. Gadjah Mada International Journal of Business. 18(2): 111-130.

- Thamizhvanan A dan Xavier MJ. 2012. Determinants of customers'online purchase intention: An empirical study in India. Journal of Indian Business Research.5(1):17-32.

- Tolba A, Souedi I, Fahmi K. 2016. Factors influencing intentions of Egyptian MSME owners in taking commercial bank loans. Journal of Small Business \& Entrepreneurship. 27(6): 497-518.

- Ueasangkomsate P. 2015. Adoption e-commerce for export market of small and medium enterprises in Thailand. Procedia Social and Behavioral Sciences. 207:111-120.

- Venkatesh J, Kumari RL, 2015. The application of e-commerce in Indian MSME sector. International Journal of Management and Social Science Research Review. 1(14): 49-55.

- Wickramasinghe V, Fernando D. 2017. 2017. Use of microcredit for household income and consumption smoothing by low income communities. International Journal of Consumer Studies. 2017:1-12. DOI: 10.1111/ijcs.12378. 